\title{
Utilization of Financial Resources and Development of School Facilities and Services for Students and Teachers of Esperanza National High School
}

DOI: https://doi.org/10.47175/rielsj.v2i3.297

\section{| Karlyn B. Rico, MAT |}

Esperanza National High School, Poblacion, Esperanza, Sultan Kudarat, Region XII, Philippines

*karlynbrico@gmail.com

\begin{abstract}
This study is a descriptive correlational study which determined the impact of the utilization of financial resources on the development of school facilities and services for students and teachers. Teachers, Supreme Student Council (SSG) Officers, class mayors, student athletes, Parent-Teacher Association (PTA) Officers, disbursing officer, bookkeeper and supply officer were the respondents of this study. They gave a reliable information regarding the utilization of financial resources. Findings revealed that Maintence and Other Operating Expenses (MOOE), Special Education Fund (SEF) and other financial resources were well implemented and the development they have given to the school facilities and services for students and teachers was very satisfactory. Effective utilization of MOOE increased the positive perceptions of the respondents about the welfare and development of school facilities and services for students and teachers in terms of academic achievement and other school performance indicators. Thus, MOOE and SEF should be utilized according to the approved budget where the teachers, PTA officers and School Governing Council (SGC) members will be part of the budget hearing. School administrators should involve all the teachers and some stakeholders in budget planning and implementation and should follow the budget specifications in planning and implementation to avoid diversion of funds.

KEYWORDS;

utilization; financial resources; development; school facilities; services
\end{abstract}

\section{INTRODUCTION}

The financial resources are the most influential tools to improve both school's physical and human resources. That's why, apart from curricular reforms and capacity building programs, the Department of Education (DepEd) continues to allocate more funds to public schools to support them in performing their ultimate task to educate the students to become better citizens of the country (DepEd Order No. 13, s. 2016).

The welfare of the state depends largely upon the education of its citizens. The state should establish and maintain a complete and adequate system of instruction. Funds should be provided for the public schools to give quality education for children of school age. Two of the major financial resources of the public schools are Maintenance and Other Operating Expenses (MOOE) and Special Education Fund (SEF). Other school funds come from Parent-Teacher Association (PTA), Canteens, fundraising, Income Generating Projects (IGP), donations and feeding budget (Palma, 2018).

To ensure accountability in the use of MOOE, SEF and other government funds, all schools are mandated by the Republic Act 9485 also known as "Anti-Red Tape Act of 2007" 
to post a Transparency Board on MOOE and SEF expenditures. Further, Section 2 of the Presidential Decree No. 1445 which emphasizes that all resources of the government shall be managed, spent or used in compliance with existing laws, guidelines and regulations, and being protected against unnecessary loss or illegal expenditure. Utilization of financial resources is very precarious since many are looking into how the school resources are managed. Palma (2018) stressed that teachers, parents and students deserve to know where the funds will be utilized.

Further, effective utilization of financial resources is the systematic way of ensuring an organization to run efficiently within allotted budget. It is a discipline dealing with the financial decisions that schools make, and the tools and analysis used to make decisions. Its major goal is to improve the way the school functions by appropriately forecasting, recording, and executing measures related to the school budget. Success in the utilization of school funds solely depends on the school leader. High integrity coupled with right skills and training in handling school funds is one of the best qualities of school administrators to effect positive change in the school environment (Petrick, 2015).

DepEd Order No. 13, s. 2016 aims to give clear direction to all public schools on the source, release and the utilization of school MOOE. It also ensures judicious and ideal use of school resources and to implement mechanisms for transparency and accountability. Further, DepEd Order No. 10, s 2017 known as the "Revised Guidelines on the use of the Special Education Fund" aims to update the policies and guidelines contained in previous JCs of the DepEd, DBM and DILG on the use and purpose of the SEF as provided under Republic Act No. 7160 or the Local Government Code (LGC) of 1991 and its implementing Rules and Regulations (IRR).

On the other hand, quality education is the need of modern societies. The capacity of educational leaders to provide the relevant learning experiences for learners in the dynamic and ever-changing world has driven schools to become responsive since the $21^{\text {st }}$ century education demands for better preparation of learners in the basic education to equip learners with the necessary knowledge, skills, values and attitudes. As emphasized by Manasan and Castel (2009), many of the causes of poor school development and lower extent of teachers' productivity are attributed to factors such as the lack of curriculum framework, mismanagement of school resources, poor staff relationship, ineffectiveness teaching practice, and poor academic performance of students.

The MOOE, SEF and other financial resources play a gargantuan task of helping school for its development in terms of teachers' training to improve learning outcomes, physical plant and facilities, ground maintenance, repair of the tools and equipment, conduct of school activities, communication services, reproduction of learning resources and funding educational researches to address learning difficulties. Getting a documented feedback from selected stakeholders who serve as the respondents plays a vital role to improve the utilization of school funds. Thus, this research was conducted.

\section{Conceptual Framework}

The Philippine government has enormous part in achieving the Education for All (EFA) goals, generally through creation and implementation of programs and provision of services that gear towards development of the formal school system in the country. Republic Act 9155 emphasizes that every Filipino has the right to acquire quality education.

Dela Cruz (2018) stressed that MOOE is still not enough to accommodate all the basic services of the school. This is how RA No. 5447 created the SEF. It is utilized as supplemental fund for basic education programs and projects and cannot be disbursed for school fees. SEF is one of the most logical vehicles for reform in pursuit of quality education. 
LGUs are key players for the basis of positive and collective action with the DepEd that will lead to improvement of learning outcomes (Robredo, 2008). The aforementioned policy has to be monitored, ensuring that its purpose is being fulfilled and its assessment reflects the true status and accomplishments.

Utilization of MOOE (activities in the approved School Improvement Plan (SIP) and Annual Implementation Plan (AIP) in terms of school-based training and activities, special curricular programs, utilities and communications, school supplies and other consumables, major school activities, wages of janitorial and security services, minor school repairs, small capital expenditure items, reproduction of teacher-made activities or exercises, rental and minor repair of tools and equipment and instructional materials will serve as the first independent variable of the study. Utilization of SEF relative to construction and repair of school buildings, facilities and equipment, purchase of books and periodicals and sports development will serve as the second independent variable of the study

Good financial practice means wisely managing school funds so that budget is anchored with the school's developmental plan. Effective budgeting improves the internal efficiency of the school. If the financial resources are spent wisely, school development will be expected. Development of school facilities in terms of buildings, ground maintenance, classrooms, faculty rooms, library resources and laboratory rooms will serve as the first dependent variable of the study. Development of services for students and teachers relative to student development, teachers' trainings and seminars, culture of research, provision of learning materials and sports activities will serve as the second dependent variable of the study.

The following conceptual framework depicts how the school development will be influenced by the utilization of the MOOE, SEF and other financial resources. The arrow connecting the two boxes illustrates how the financial resources will affect the development of school if not utilized in accordance with the DepEd Order No. 13, s. 2016 and RA No. 5447.

\section{INDEPENDENT VARIABLES}

\begin{tabular}{|c|c|}
\hline $\begin{array}{l}\text { Utilization of Maintenance and Other } \\
\text { Operating Expenses (MOOE) } \\
\text { (Activities in the Approved SIP and AIP) } \\
\text { - } \quad \text { School-Based Training and Activities } \\
\text { - } \quad \text { Special Curricular Programs } \\
\text { - } \quad \text { Utilities and Communications } \\
\text { - } \quad \text { School Supplies and Other Consumables } \\
\text { - } \quad \text { Major School Activities } \\
\text { - } \quad \text { Wages of Janitorial and Security Services } \\
\text { - } \quad \text { Minor School Repairs } \\
\text { - } \quad \text { Small Capital Expenditure Items } \\
\text { - } \quad \text { Reproduction of Teacher-Made Activity } \\
\text { - Sheets and Exercises } \\
\text { Rental and Minor Repair of Tools and } \\
\text { Equipment } \\
\text { Instructional Materials } \\
\text { Utilization of Special Education Fund (SEF) } \\
\text { - Construction and Repair of School } \\
\text { Buildings } \\
\text { - Facilities and Equipment } \\
\text { Educational Research }\end{array}$ & $\begin{array}{ll}\text { Development of School Facilities } \\
\text { - } \quad \text { Buildings } \\
\text { - } \quad \text { Ground Maintenance } \\
\text { - } \quad \text { Classrooms } \\
\text { - } \quad \text { Faculty Rooms } \\
\text { - } \quad \text { Library Resources } \\
\text { - } \quad \text { Laboratory Rooms } \\
\text { Development of Services for } \\
\quad \text { Students and Teachers } \\
\text { - Student Activities } \\
\text { - Teachers' Trainings and } \\
\quad \text { Seminars } \\
\text { - Culture of Research } \\
\text { - } \quad \text { Provision of Learning } \\
\quad \text { Materials } \\
\text { - Sports Activities }\end{array}$ \\
\hline
\end{tabular}

Figure 1. Research Paradigm 


\section{Statement of the Problem}

This study aimed to determine the impact of the utilization of financial resources on the productivity of Esperanza National High School in terms of facilities and services for students and teachers.

Specifically, this study was carried out to answer the following questions:

1. What is the extent of utilization of Maintenance and Other Operating Expenses (MOOE) relative to:

1.1 School-Based Training and Activities;

1.2 Special Curricular Programs;

1.3 Utilities and Communications;

1.4 School Supplies and Other Consumables;

1.5 Major School Activities;

1.6 Wages of Janitorial and Security Services;

1.7 Minor School Repairs;

1.8 Small Capital Expenditure Items;

1.9 Reproduction of Teacher-Made Activity Sheets or Exercises;

1.10 Rental and Minor Repairs of Tools and Equipment; and

1.11 Instructional Materials?

2. What is the extent of utilization of Special Education Fund (SEF) relative to:

2.1 Construction and Repair of School Buildings;

2.2 Facilities and Equipment;

2.3 Educational Research;

2.4 Sports Development; and

2.5 Salaries of Some Security Guards?

3. What is the level of development of school facilities in terms of:

3.1 Buildings;

3.2 Ground Maintenance;

3.3 Classrooms;

3.4 Faculty Rooms;

3.5 Library Resources; and

3.6 Laboratory Rooms?

4. What is the level of development of services for students and teachers in terms of:

4.1 Student Activities;

4.2 Teachers' Trainings and Seminars;

4.3 Culture of Research;

4.4 Provision of Learning Materials; and 4.5 Sports Activities?

5. Is there a significant relationship between the utilization of financial resources and school development of Esperanza National High School?

\section{RESEARCH METHODS}

\section{Research Design}

This study employed a descriptive correlational research design that appraised carefully the worthiness of the variables involved. This research design had undergone three premises in gathering necessary data. First, information for the school funds and productivity of Esperanza National High School was collected, averaged and synthesized using descriptive statistics. Second, after determining the average score for each variable, the extent to which the variables' scores using the set criteria for each variable was determined. Third, inferential 
statistics was utilized to examine the relationship of the utilization of school funds and productivity of Esperanza National High School.

\section{Respondents of the Study}

Teachers, Supreme Student Council (SSG) Officers, class mayors, student athletes, ParentTeacher Association (PTA) Officers, disbursing officer, bookkeeper and supply officer were the respondents of this study. They were the ones to give reliable information regarding the utilization of MOOE, SEF and other school funds.

\section{Sampling Technique}

A purposive sampling technique was employed in identifying the disbursing officer, bookkeeper, supply officer and student athletes. Complete enumeration was applied to all Parents-Teachers Association (PTA) officers, Supreme Student Government (SSG) officers and class mayors. To determine the number of teacher-respondents, Raosoft online sampling size was utilized. For specific identification of teacher-respondents, simple random sampling was used to determine the actual teacher-respondents. Table 1 presents the sample of the study.

Table 1. Sample of the Study

\begin{tabular}{clcc}
\hline \multicolumn{2}{c}{ Types of Respondent } & Sample & Percentage \\
\hline 1 & Teachers & 120 & 53.10 \\
2 & SSG Officers & 10 & 4.42 \\
3 & Class Mayors & 60 & 26.55 \\
4 & Student Athletes & 15 & 6.64 \\
5 & PTA Officers & 10 & 4.42 \\
6 & Disbursing Offer & 1 & 0.44 \\
7 & Bookkeeper & 1 & 0.44 \\
8 & Supply Officer & 1 & 0.44 \\
9 & Local School Board & 8 & 3.55 \\
\hline \multicolumn{2}{c}{ Total } & $\mathbf{2 2 6}$ & $\mathbf{1 0 0}$ \\
\hline
\end{tabular}

\section{Research Instrument}

Research instrument is a measuring tool designed to obtain data on a topic of interest from research subjects. Hence, a researcher-made questionnaire was used to gather information about the relevant data needed in this study. The research instrument (See the attached research instrument) consists of five (5) parts.

The first part of the research questionnaire elicited the extent of the utilization of MOOE. It is subdivided into twelve (11) indicators. The second part solicited the extent of the utilization of the SEF. It is composed of six (5) indicators. The third part determined the level of development of school facilities with six (6) indicators. The fourth part described the level of development of services for students and teachers with five (5) indicators.

\section{Data Gathering Methods}

After finding out that this research entitled "Utilization of Financial Resources and Development of School Facilities and Services for Students and Teachers of Esperanza National High School" was approved by the Basic Education Research Fund (BERF) for its implementation, validation of research instrument was secured. Subsequently, coordination and approval letter from the office of the Division Office of DepEd - Sultan Kudarat was sought. After getting approval letter to conduct the study, orientation of the respondents was conducted. Online distribution of the research instrument to the respondents 
automatically followed. The respondents were given ample time to answer the survey questionnaire. Online retrieval of the research instrument was done as soon as the respondents finally answered all items of the survey questionnaire. After all quantitative data were collected and tabulated, data analysis and interpretation of data was the last stage of data gathering procedure.

\section{Data Analysis}

The quantitative data gathered from the respondents were tallied using the Microsoft Excel with the help of Social Package for Social Sciences (SPSS) in order to obtain computer generated analyses. Descriptive statistics such as weighted mean and inferential statistics like as Pearson $r$ were employed.

Weighted mean was employed to determine the extent of the utilization of MOOE, SEF and other school funds as well as the level of the productivity of the school (research questions 1, 2, 3 and 4). Pearson's $r$ was applied to determine the relationship between the utilization of school funds and the productivity of Esperanza National High School.

The responses of the respondents in the utilization of financial resources for each question were analyzed using the 5-Point Likert Scale with the following description:

Table 2. Responds of respondents

\begin{tabular}{|c|c|c|}
\hline $\begin{array}{c}\text { Numerical } \\
\text { Rating }\end{array}$ & $\begin{array}{c}\text { Qualitative } \\
\text { Rating }\end{array}$ & $\begin{array}{c}\text { Descriptive } \\
\text { Interpretation }\end{array}$ \\
\hline 5 & Strongly Agree & Utilization of the school funds is VERY WELL IMPLEMENTED. \\
\hline 4 & Agree & Utilization of the school funds is WELL IMPLEMENTED. \\
\hline 3 & Moderately Agree & Utilization of the school funds is SLIGHTLY IMPLEMENTED. \\
\hline 2 & Disagree & Utilization of the school funds is POORLY IMPLEMENTED. \\
\hline 1 & Strongly Disagree & Utilization of the school funds is NOT IMPLEMENTED. \\
\hline
\end{tabular}

\section{RESULTS AND DISCUSSION}

\section{Utilization of Maintenance and Other Operating Expenses (MOOE)}

The extent of the utilization of MOOE was determined through the responses of the five types of respondents such as Local School Board (LSB) members, assistant principals, disbursing officers, teachers, parents and student leaders and athletes. Table 3 presents the results.

Table 3. Extent of Utilization of Maintenance and Other Operating Expenses (MOOE)

\begin{tabular}{llll}
\hline Utilization of MOOE & Mean & Description \\
\hline 1 & School-Based Training and Activities & 4.26 & Very Well Implemented \\
2 & Special Curricular Programs & 4.30 & Very Well Implemented \\
3 & Utilities and Communications & 4.43 & Very Well Implemented \\
4 & School Supplies and Other Consumables & 4.41 & Very Well Implemented \\
5 & Major School Activities & 4.21 & Very Well Implemented \\
6 & Wages of Janitorial and Security Services & 4.23 & Very Well Implemented \\
7 & Minor School Repairs & 4.18 & Well Implemented \\
8 & Small Capital Expenditure Items & 4.18 & Well Implemented \\
9 & Reproduction of Teacher-Made Activity Sheets or & 4.21 & Very Well Implemented \\
& Exercises & & \\
10 & Rental and Minor Repairs of Tools and Equipment & 4.18 & Well Implemented \\
11 & Instructional Materials & 4.28 & Very Well Implemented \\
\hline Overall Mean & $\mathbf{4 . 2 2}$ & Very Well Implemented \\
\hline
\end{tabular}

Legend: 4.20 - 5.00 - Very Well Implemented; 3.40 - 4.19 - Well Implemented;

$2.60-3.39$ - Slightly Implemented; $1.80-2.59$ - Poorly Implemented;

$1.00-1.79$ - Not Implemented 
As shown, the overall mean of 4.22 described as "Very Well Implemented" indicates that the school effectively managed, expended or utilized the MOOE in accordance with law and regulations, and safeguarded the said resources against loss or wastage. The overall result was affirmed by 6 out 12 indicators that received a verbal description of "Very Well Implemented" assessment. In other words, school efficiently ensured efficiency, economy and effectiveness in the delivery of basic services to the clienteles, the learners with the help of MOOE. Their responsibility to legally utilize the said resources was commendable.

In particular, the highest mean of 4.43 described as "Very Well Implemented" was obtained by "Utilities and Communications". This means that payment of the expenses for utilities and communications for the improvement of the school was very well evident. In other words, water bills, electric bills, internet bills, telephone bills and other means of communications were paid on time and no delay of payment of expenses was observed.

On the other hand, the lowest mean of 4.18 described as "Well Implemented" only was acquired by "Minor School Repairs", "Small Capital Expenditures" and "Rental and Minor Repairs of Tools and Equipment". Due to this COVID-19 pandemic, minor repair school repairs, small capital expenditures and rental and repairs of tools and equipment were well implemented only since no students are in the school.

This study is consistent with the Joint Circular (JC) No. 1, series of 2017 issued by Department of Education (DepEd), Department of Budget and Management (DBM) and Department of the Interior and Local Government (DILG) which ensures a more strategic and efficient utilization of resources for priority programs and projects such as school facilities and equipment which would complement and reinforce instructional practices.

Catanduanes Tribune (2011) stressed that MOOE is beneficial to the school. However, if not managed properly, it can cause conflict between the principal and the teachers, and to prevent this from happening, principals especially the newly-promoted school heads should follow the guidelines in managing this fund, always communicate with the teachers, involve them in decision-making, and be very transparent and honest in all transactions.

It is stressed by this study that school heads should be very transparent with regards to the financial resources of the school. They should orient their teachers about the major financial resources of the school such as Maintenance and Other Operating Expenses (MOOE), Special Education Fund (SEF), Donations, Canteens, Income Generating Projects and other sources. Many teachers are not aware of the whereabouts of these school funds. Particularly, the school heads should emphasize to the teachers that the latter can request from SEF with regards to their major references if not available in the library so that learning opportunities of the students will be maximized.

\section{Utilization of Special Education Fund (SEF)}

Utilization of SEF refers to the effective and efficient use of funds taken from $1 \%$ of the real property tax of Esperanza, Sultan Kudarat by the school administrators, District Supervisors and Local School Board (LSB) members. Table 4 presents the extent of utilization of special education fund (SEF).

Table 4. Extent of Utilization of Special Education Fund (SEF)

\begin{tabular}{|c|c|c|c|}
\hline & Utilization of SEF & Mean & Description \\
\hline 1 & Construction and Repair of School Buildings & 4.22 & Very Well Implemented \\
\hline 2 & Facilities and Equipment & 4.20 & Very Well Implemented \\
\hline 3 & Educational Research & 4.08 & Well Implemented \\
\hline 4 & Purchase of Periodicals & 3.83 & Well Implemented \\
\hline 5 & Sports Development & 4.10 & Well Implemented \\
\hline \multicolumn{2}{|r|}{ Overall Mean } & 4.09 & Well Implemented \\
\hline
\end{tabular}


Legend: 4.20 - 5.00 - Very Well Implemented; 3.40 - 4.19 - Well Implemented; 2.60 - 3.39 - Slightly Implemented; 1.80 - 2.59 - Poorly Implemented; $1.00-1.79$ - Not Implemented

As shown, the overall mean of 4.09 described as "Well Implemented" indicates that utilization of SEF was to the high extent. This high extent of utilization of SEF was affirmed by 2 indicators that were verbally described as "Very Well Implemented" and 4 indicators that received a verbal rating of "Well Implemented". This means that school utilized the SEF based from the Joint Circular (JC) No. 1, s. 2017 issued by Department of Education (DepEd), Department of Budget and Management (DBM) and Department of the Interior and Local Government (DILG). In other words, SEF was benefited by both the teachers and students to deliver quality education.

In particular, the highest mean of 4.22 described as "Well Implemented" was obtained by "Construction and repair of school buildings". This means that school allocated enough budget coming from SEF for the construction and repair of makeshift buildings to accommodate increasing number of students.

On the other hand, the lowest mean of 3.83 described as "Well Implemented" also was generated by "Purchase of books and periodicals". This means that SEF was utilized to the high extent for the purchase of supplemental learning materials. However, these materials are not enough to accommodate huge number of students. It is suggested that purchase of supplemental learning materials such as magazines, pamphlets, journals, periodicals and newspapers should be considered top priority since learners can really get new updates from these learning resources.

The second to the lowest mean of 4.08 described as "Well Implemented" also was garnered by "Educational research". This means that there were researches funded through SEF. However, promoting the culture of research in the school was among the last priorities of the school. Although majority of the teachers were aware that there was budget for the educational research from SEF, they were not yet motivated to conduct action researches to answer social issues affecting students' performance and behaviors.

This study is related to the findings of De Guzman (2015) when she found out that the utilization of SEF for educational research received the lowest extent and it was the operation and maintenance of public schools that registered the highest allocations of budget. In addition to this, Legaste (2018) found out that only very few teachers submitted research proposals asking funding from SEF. He also stressed that many public school teachers in Sultan Kudarat were not yet capacitated in conducting educational research. He further recommended that public school administrators should orient the teachers that the latter can request a funding of their researches from $\mathrm{SEF}$.

The result of this research is a wake-up call for the public school administrators to do something to establish the culture of research among the teachers. Inviting well known speakers to talk about action researches should be included in the planning particularly during Midyear Performance, Review and Evaluation (MPRE). Studies reveal that the reason why other countries are developed in terms of technology is because they are performing very well in research.

It is hereby enjoined that school administrators and members of Local School Board (LSB) should establish close coordination with the Local Government Unit (LGU) so that efficient release of the Special Education Fund (SEF) will be ensured. Teachers should also be consulted as to the priority needs of the learners so that effective delivery of the lessons will be observed. 


\section{Utilization of Other Financial Resources (PTA, fundraising, donations, canteens and feeding)}

Aside from the MOOE and SEF allocated to the school for its maintenance and operation for the welfare of the students, other financial resources such as PTA, fundraising, donations, canteens and feeding program fund are also very vital to fund school programs and activities which are beyond the allocations from MOOE and SEF. Table 5 presents the extent of utilization of other financial resources of the school.

Table 5. Extent of Utilization of Other Financial Resources (PTA, fundraising, donations, canteens and feeding)

\begin{tabular}{|c|c|c|}
\hline $\begin{array}{l}\text { Utilization of Other Financial } \\
\text { Resources (PTA, fundraising, } \\
\text { donations, canteens and feeding) }\end{array}$ & Mean & Description \\
\hline $\begin{array}{ll}1 & \text { Construction and Repair of School } \\
\text { Facilities }\end{array}$ & 4.21 & Very Well Implemented \\
\hline 2 Student Development & 4.17 & Well Implemented \\
\hline Feeding Program & 4.26 & Very Well Implemented \\
\hline $\begin{array}{l}4 \text { Purchase of Supplementary } \\
\text { Instructional Materials }\end{array}$ & 4.25 & Very Well Implemented \\
\hline 5 Medicine & 4.24 & Very Well Implemented \\
\hline Overall Mean & 4.23 & Very Well Implemented \\
\hline
\end{tabular}

As shown, the overall mean of 4.23 described as "Very Well Implemented" indicates that there was an outstanding utilization of other school financial resources. This was affirmed by 4 out of 5 indicators that received the rating of "Very Well Implemented". This means that there were no irregularities in the allocation and utilization of the funds coming from PTA, donations, canteens and other sources to fund school programs and activities beyond the capacity of MOOE and SEF.

In particular, the highest mean of 4.26 described as "Very Well Implemented" was obtained by "Feeding program". This indicates that there was an excellent implementation of the feeding program activities wherein all funds intended for the program was utilized to the highest extent.

On the other hand, the lowest mean of 4.17 described as "Well Implemented" sa acquired by "Student development". Although, there was a high extent of utilization of school funds for student development, it is expected that this would be the top concern of the student since students are the direct beneficiaries of the program. It is indeed suggested that student development programs and activities should be designed and given enough allocations so that students will be given more opportunities to learn and socialize with other students.

In relation to this study, Geminiano (2016) stressed that discipline, teamwork and sportsmanship are enhanced during student development programs Thus, the schools should utilize all the needed financial resources for the social development of the students.

Thus, school administrators should include student development in the priority programs and policy formulation so that students will be holistically developed through sports.

\section{Development of School Facilities and Services for Students and Teachers}

If school funds particularly the MOOE and SEF are religiously utilized in accordance with the legal bases, many benefits will be expected by the students. Problems 4 and 5 of the 
present study pertains to the extent of the development of school facilities and services for students and teachers. The results are shown in Tables 6 and 7.

Table 6. Extent of Development of School Facilities

\begin{tabular}{llll}
\hline Development of School Facilities & Mean & Description \\
\hline 1 & Buildings & 4.22 & Highly Evident \\
2 & Ground Maintenance & 4.26 & Highly Evident \\
3 & Classrooms & 4.05 & Evident \\
4 & Offices and Faculty Rooms & 4.07 & Evident \\
5 & Library Resources & 3.73 & Evident \\
6 & Laboratory Rooms & 3.75 & Evident \\
\hline Overall Mean & $\mathbf{4 . 0 5}$ & Evident \\
\hline
\end{tabular}

Legend: 4.20 - 5.00 - Highly Evident; 3.40 - 4.19 - Evident;

2.60 - 3.39 - Moderately Evident; 1.80 - 2.59 - Poorly Evident; $1.00-1.79$ - Not Evident

As shown, the overall mean of 4.05 with a verbal description of "Evident" shows that there was really a high extent of development of school facilities as a result of effective utilization of financial resources. In other words, the provision of MOOE, SEF and other school funds was really benefited by the school through its development of facilities. Financial resources were effectively utilized for development school facilities.

Particularly, "Ground maintenance" and "Buildings" received the first two highest means of 4.26 and 4.22 all described as "Highly Evident", respectively. This indicates that upkeep of the school premises and construction of buildings were the top priorities of the school. In other words, due to the MOOE, SEF and other school funds, the school facilities improved and maintained.

In different manner, the two lowest means of 3.73 and 3.75 all described as "Evident" were received by "Library resources" and "Laboratory rooms", respectively. This implies that there was still a need of books and other supplemental learning materials in the library. The books and periodicals supplied by the DepEd really cannot accommodate the increasing number of student population and MOOE and SEF cannot answer all those shortages of books and other supplemental learning materials since huge amount of financial resources would be needed. Research shows that students nowadays are more exposed with online materials than physical library (printed) materials. That's why, students appealed to the concerned individuals to enhance the internet connection and enough funds should be allocated in this purpose. Further, laboratory rooms need to be equipped with sufficient apparatuses so that practical work activities of students can be maximized.

Table 7. Extent of Development of Services for Students and Teachers

\begin{tabular}{llll}
\hline Development of Services for Students and Teachers & Mean & Description \\
\hline 1 & Student Activities & 3.88 & Evident \\
2 & Teachers' Trainings and Seminars & 3.85 & Evident \\
3 & Culture of Research & 4.16 & Evident \\
4 & Provision of Learning Materials & 3.83 & Evident \\
5 & Sports Activities & 3.86 & Evident \\
\hline Overall Mean & 3.92 & Evident \\
\hline \multicolumn{4}{c}{ Legend: 4.20 - 5.00 - Highly Evident; 3.40-4.19- Evident; } \\
\multicolumn{3}{c}{ 1.60 - 3.39- Moderately Evident; 1.80-2.59 - Poorly Evident; } \\
\end{tabular}


As shown, the overall mean of 3.92 with a description of "Evident" implies that development of services for students and teachers was manifested. This means that both students and teachers benefited from the effective implementation of the financial resources of the school. This evident development of services for students and teachers was affirmed by all indicators that received a descriptive rating of "Evident".

Apparently, "Culture of research" received the highest mean of 4.16 described as 'Evident". This means that teachers were active in conducting action researches for the welfare and development of students particularly to improve the performance indicators of the school. This was manifested for the 3 consecutive years wherein Esperanza National High School was known to be the school with highest number of approved action researches funded by Basic Education Research Fund (BERF).

In different manner, "Provision of learning resources" acquired the lowest mean of 3.83 described as "Evident" also. This implies that there was a development of the process of providing learning materials for instructional activities. However, learning materials should be provided to accommodate the increasing number of students. This shortage of learning materials can be augmented by the budget coming from the SEF and other sources. Indeed, some portion of SEF should be appropriated to make the learning materials adequate for the students. Providing students with important opportunities to practice a new skill gained in class was one of the priorities of the SEF and other school funds.

The $21^{\text {st }}$ century learning requires variety of instructional materials to make the students be par at the rest of the world. Teaching becomes interesting when the teacher employs variety of instructional materials suited to learning styles of the students. Thus, school should allocate big appropriations from the school funds to augment the shortage of learning materials needed by the students as well the tools and equipment needed for practical exercises.

\section{Utilization of Financial Resources and School Development of School Facilities and Services for Students and Teachers of Esperanza National High School}

Financial management of school administrators implies judicious utilization of all available school resources such as MOOE, SEF and other school funds for the attainment of the defined goals of the schools. It therefore deals with the provision, custody and disbursement of the financial resources needed for running the schools. The relationship of utilization of MOOE and SEF and the development enjoyed by the school is investigated by this study and the results are shown in the following table.

Table 8. Correlation Analysis on the Impact of Financial Resources on Development of School Facilities and Services for Students and Teachers

\begin{tabular}{lllll}
\hline $\begin{array}{l}\text { Development of School Facilities and } \\
\text { Services for Students and Teachers }\end{array}$ & $\mathbf{r}$ & $\mathbf{t}_{\text {comp }}$ value & $\mathbf{t}_{\text {crit }}$ value \\
\hline 1 & MOOE & $0.763^{*}$ & 13.197 & 1.979 \\
2 & SEF & $0.869^{*}$ & 19.635 & 1.979 \\
\hline
\end{tabular}

* - significant @0.05 level

MOOE and Development of School Facilities and Services for Students and Teachers. Table 6 presents the first correlation coefficient, $r_{1}=0.763$, which was significant since the $t_{\text {comp }}=13.197$ is greater than the $t_{\text {critical }}=1.979$. This means that the utilization of MOOE was significantly related to the development of school facilities and services for students and teachers. In other words, the higher the extent of the utilization of MOOE, the better the benefits received by both the students and teachers. Effective utilization of MOOE 
increased the positive perceptions of the respondents about the welfare and development of school facilities and services for students and teachers in terms of academic achievement and other school performance indicators.

The study of Cerado (2016) supports the above data when he found out that SEF expenditures were related to students' learning outcomes such as National Achievement Test (NAT), completion rate, graduation rate and participation rate among students. This statistical finding is also supported and contrasted by Tow (2016) who found out that school funding has a positive effect on student academic achievement.

SEF and Development of School Facilities and Services for Students and Teachers. Moreover, Table 6 also shows the second correlation coefficient, $r_{2}=0.869$, which was also significant since $t_{\text {comp }}=19.635>t_{\text {critical }}=1.979$. This indicates that the utilization of SEF was significantly related to the current status of the school facilities and services for students and teachers. This also means that the higher the extent of SEF utilization, the higher the chance that school facilities and services for students and teachers will improve. This implies that school facilities and services for students and teachers were developed by the effective utilization of SEF.

This finding is supported by Oluremi and Olubukola (2013) who emphasized that school funds are significantly related to school physical facilities and equipment. They noted that if school resources are effectively utilized for the procurement of the equipment and for the maintenance of the school physical facilities, the students are motivated to improve their performance and demonstrate positive behavior.

Other Financial Resources and Development of School Facilities and Services for Students and Teachers. Since that the $t_{\text {comp }}=12.412$ is greater than the $t_{\text {critical }}=1.979$, the third correlation coefficient, $\mathrm{r}_{3}=0.743$, was significant. This means that other financials resources such as PTA legal dues, donations, fundraising, canteens and feeding program funds had great benefits to develop school facilities and services for students and teachers. In other words, if there is an effective utilization of financial resources, there is a positive impact on the development and welfare of the school, students and teachers.

Oboegbulen (2013) stated that school resources are associated with educational achievement. He claimed that there is a positive relationship between educational spending and educational output. He reiterated that the higher the expenditures of the schools, the better the educational outcomes of the students. He concluded that increase in school expenditure reduces dropout rate but have limited effects on student test scores. He recommended that schools should have enough expenditures pertaining to instructional materials so that adequacy of the learning resources in the library will be evident.

\section{CONCLUSION}

The extent of utilization of MOOE, SEF and other financial resources was well implemented and the development it has given to the school facilities and services for students and teachers were very satisfactory. The higher the extent of utilization of MOOE, SEF and other financial resources, the better the development of the school is. Effective utilization of MOOE increased the positive perceptions of the respondents about the welfare and development of school facilities and services for students and teachers in terms of academic achievement and other school performance indicators.

\section{Recommendation}

Based on the findings and conclusions, following recommendations were formulated to improve the implementation of Maintenance and Other Operating Expenses (MOOE), 
Special Education Fund (SEF) and other financial resources at Esperanza National High School.

1. Maintenance and Other Operating Expenses (MOOE) and Special Education Fund (SEF) should be utilized according to the approved budget where the teachers, PTA officers and School Governing Council (SGC) members will be part of the budget hearing. In other words, school administrators should involve all the teachers and some stakeholders in budget planning and implementation. School administrators should follow the budget specifications in planning and implementation to avoid diversion of funds.

2. Special Education Fund (SEF) should be directly given to the public high schools and this would not anymore pass through the administration of the District Supervisor since the school itself determines what is needed by the teachers and students.

3. Enough appropriations of SEF should be allotted for funding educational researches which investigate prevailing factors on how to enhance instructional practices and to achieve accessible and quality learning outcomes.

4. School administrators should lawfully and ethically utilize MOOE and SEF and other school funds for the operation and maintenance of the schools, conduciveness of the school environment and effective learning opportunities of the children.

5. School administrator should involve the teachers and student leaders to identify the priority needs of the school to be funded by MOOE and SEF.

6. Internet facility should be maintained through MOOE and SEF in such a way that strong connection in the library should be observed since majority of the research works are now done via online. This will go a long way to improve the standard and quality of educational outfit.

\section{REFERENCES}

Boon, T. H., H. S. Yee \& H. W. Ting (2011). Financial Literacy and Personal Financial Planning in Klang Valley, Malaysia, International Journal of Economics and Management, 5(1): 149 - 168.

Dela Cruz, E. U. (2018). Utilization of Special Education Fund (SEF): A Procurement Model, Doctoral Dissertation, University of the Visayas, Cebu City.

De Guzman, J. (2015). Utilization of Special Education Fund (SEF) and School Performance in Lambayong Municipality, Master's Thesis, Sultan Kudarat State University, ACCESS, EJC Montilla, Tacurong City.

DepEd Order No. 10, s. 2017. Revised Guidelines on the Use of the Special Education Fund.

DepEd No. 5, 2005. Implementing Guidelines on the Implementation of Gulayan sa Paaralan, Solid Waste Management and Tree Planting Under the National Greening Program (NGP).

DepEd Order No. 44, s. (2016). Guidelines on the School-to-School Partnerships for Fiscal Year 2016.

DepEd Order No. 10, s. (2017). Revised guidelines on the use of the special education fund (SEF).

DepEd Order No. 13, s. (2016). Implementing Guidelines on the Direct Release and Use of Maintenance and Other Operating Expenses (MOOE) Allocations of schools, including other funds managed by schools.

Lapada, R. O., \& Lapada, E. S. (2021). Students' Experiences, Reactions and Opinions on Bullying at Esperanza National High School, Esperanza, Sultan Kudarat, Region XII, 
Philippines. Randwick International of Education and Linguistics Science Journal, 2(2), 170-181. https://doi.org/10.47175/rielsj.v2i2.257

Manasan, R. G. \& Castel, K. (2009). Mobilizing LGU support for basic education: focus on the special education fund. Retrieved October 3rd, 2013 from http://serp-p.pids.gov.ph/serp-p/download.php?d=4984\&s=2.

Palma, M. F. (2018). Administrators' Budgeting Practices: Basis in Enhancing Fiscal Management Programs of Public Elementary Schools in Region XII, Sultan Kudarat State University, EJC Montilla, Tacurong City, Sultan Kudarat.

Petrick, J. (2015). Financial Responsibilities of Principals, retrieved at work.chron.com > financial responsibilities on May 15, 2015.

P. D. 1445. Government Auditing Code of the Philippines, Ordaining and Instituting Auditing Code of the Philippines.

Republic Act 4160, the Local Government Code of 1991.

Republic Act 5447, Creating a Special Education Fund.

Republic Act No. 9485. Anti-Red Tape Act of 2007, An act to improve efficiency in the delivery of government service to the public by reducing bureaucratic red tape, preventing graft and corruption, and providing penalties therefor.

Republic Act No. 9155. An Act Instituting a Framework of Governance for Basic Education. Republic Act No. 7160. Local Government Code of 1991.

Robredo, J. M. (2008). Naga City Mayor. Retrieved August 13, 2012 from www.naga.gov.ph.

Varela, A. D. (2016). Administration Culture and Political Change. Quezon City: College of Political Administration, University of the Philippines. 